Ks. Norbert WIDOK

(Opole, UO)

\title{
OJCOWIE KAPADOCCY W NAUCZANIU JANA PAWHA II
}

Śmierć papieża Jana Pawła II, której druga rocznica będzie w niedługim czasie wspominana, skłania do dokonania wieloaspektowych podsumowań minionego pontyfikatu. Ten był w szerokim zakresie pontyfikatem nauczania, i to zarówno w słowie pisanym, jak i głoszonym. Niezmiernie istotną jego częścią jest obecność wypowiedzi Ojców Kościoła w papieskim nauczaniu. Niniejsze opracowanie uwzględnia odniesienia do nauki Ojców Kapadockich oraz dosłowne ich wypowiedzi, które zostały przytoczone podczas publicznych wystąpień Jana Pawła II na Stolicy Piotrowej, a więc w ramach jego codziennej służby pełnienia mandatu powierzonego przez Chrystusa Piotrowi i jego następcom, czyli głoszenia Dobrej Nowiny. A zatem nie obejmuje wystąpień papieża na terenie Włoch, ani w czasie jego zagranicznych podróży. Do obowiązków wynikających $\mathrm{z}$ tak pojętej służby, utrwalonej wieloletnią tradycją i praktyką Stolicy Apostolskiej, należą: przemówienia podczas spotkań z wiernymi na modlitwie południowej „Anioł Pański” w niedziele i święta, katechezy kierowane do wiernych w każdą środę w Auli Pawła VI, homilie w czasie Mszy św. w bazylice św. Piotra lub na terenie Rzymu oraz okolicznościowe przemówienia do różnych grup w ramach audiencji prywatnych.

\section{OJCOWIE KAPADOCCY PODCZAS MODLITWY POEUDNIOWEJ „ANIOE PAŃSKI”}

Krótkie rozważania odnoszące się do bieżących spraw życia kościelnego, liturgicznego, a nawet politycznego, mające miejsce w niedziele i święta bezpośrednio przed modlitwą „Anioł Pański”, były dla Jana Pawła II okazją do korzystania także ze skarbca tradycji wczesnochrześcijańskiej. Niejednokrotnie zdarzało się bowiem, że papież powoływał się na głosy Ojców Kościoła, te zaś odnoszące się do Ojców Kapadockich są skromne, bo zaledwie dwukrotne.

Dzień wspomnienia św. Szczepana był okazją dla Jana Pawła II, by powiedzieć kilka refleksji na temat świętości i męczeństwa. W kontekście swego rozważania odniósł się do jednego z Kapadocczyków, stwierdzając: 
„Jak mówi św. Grzegorz z Nyssy, w pierwszych wiekach chrześcijaństwa, w okresie najbliższym świąt Bożego Narodzenia, oddawano cześć wielkim Świętym, którzy stali się pierwszymi świadkami Słowa Wcielonego. Św. Szczepan był jednym z nich"1.

W lecie 1996 r. papież w ramach modlitwy „Anioł Pański” omawiał tematy związane z szeroko pojętym duchowym dziedzictwem Wschodu, które w ciągu wieków na różne sposoby ubogacało wspólnoty chrześcijan na Zachodzie. Jedno z rozważań papież zatytułował Śladem Ojców Kościoła, a w nim oddał hołd Kapadocczykom w słowach:

\begin{abstract}
„Wśród wybitnych postaci Wschodu wystarczy przypomnieć trzech świętych hierarchów: św. Bazylego Wielkiego, św. Grzegorza z Nazjanzu i św. Jana Chryzostoma. Wnieśli oni nieoceniony wkład w pogłębienie chrześcijańskiej wizji Boga, podkreślając, że jest On ze swej natury niepojęty i przewyższający wszelką ludzką myśl, ale jednocześnie jest Tym, który stał się człowiekowi bliski w historii zbawienia, otwierając nam tajemnice swego życia trynitarnego oraz dając nam siebie we Wcielonym Słowie i w wylaniu Ducha Świętego"?.
\end{abstract}

Ta wypowiedź, zawierająca streszczenie trynitarnej wykładni wiary, udoskonalonej w IV wieku przez Ojców Kapadockich, znajduje się w kontekście papieskiej zachęty do jedności między chrześcijaństwem Wschodu i Zachodu.

\title{
II. OJCOWIE KAPADOCCY W KATECHEZACH ŚRODOWYCH
}

Pouczenia o randze katechizmowej, a więc systematycznego wyjaśniania prawd związanych z wiarą i moralnością, które Ojciec Święty wygłaszał do wiernych zgromadzonych w Auli Pawła VI lub na Placu św. Piotra, stały się kolejną możliwością odwoływania się do mądrości epoki patrystycznej. W katechezach środowych Ojcowie Kościoła pojawiają się zdecydowanie częściej, aniżeli w rozważaniach na „Anioł Pański”. Przyczynia się do tego bez wątpienia charakter tych wystąpień: są one o wiele dłuższe i odnoszą się niejednokrotnie do trudnych zagadnień doktryny katolickiej. Jest więc miejsce na to, by odwołać się do dziedzictwa patrystycznego i skorzystać z myśli już wówczas podanych i przechowanych do naszych czasów.

Papież Jan Paweł II katechezy środowe po większej części wygłaszał w cyklach tworzących zamkniętą całość tematyczną. Pierwsze jednak jego katechezy dotyczyły tematów bieżących, odnoszących się do różnych okolicz-

${ }^{1}$ Plomień świętości i męczeństwa (26 XII 1983), w: Aniot Pański z Papieżem Janem Pawłem II, II, Città del Vaticano, 1986, 270.

2 Śladem Ojców Kościoła (4 VIII 1996), w: Anioł Pański z Papieżem, VI, Roma 1998, 266, lub OsRomPol 17 (1996) nr 10, s. 27. 
ności życia liturgiczno-kościelnego. Po raz pierwszy odniesienie do jednego z Ojców Kapadockich pojawia się w katechezie na temat jałmużny. Papież stwierdził wówczas:

„A Ojcowie Kościoła powiedzą potem ze św. Piotrem Chryzologiem: [...], i ze św. Grzegorzem z Nazjanzu: «Pan wszystkich rzeczy chce miłosierdzia, nie ofiary; a my je świadczymy za pośrednictwem ubogich" "3.

Następnie Ojciec Święty przystąpił do omówienia zagadnień związanych z teologią małżeństwa. W tych katechezach nie pojawiają się odwołania do Ojców Kapadockich. W kolejnym cyklu środowego nauczania papież podjął trudną tematykę, a mianowicie dotyczącą Trójcy Świętej ${ }^{4}$. Wiadomo, że zagadnienia trynitarne stanowiły dla Ojców Kościoła niezmiernie istotny problem ze względu na powstałe wówczas błędne opinie w rozumieniu i wyjaśnianiu wzajemnych relacji Boskich Osób. Wkład wczesnochrześcijańskich myślicieli w przygotowanie ostatecznych orzeczeń jest więc przeogromny, co papież jednoznacznie podkreślał w swych katechezach. Bardzo wymowna jest taka oto jego wypowiedź:

„Po długotrwałych rozważaniach prowadzonych przez Ojców Kościoła i wyrażanych w orzeczeniach Soborów, Kościół mówi o Ojcu, Synu i Duchu Świętym jako o trzech «Osobach», które wspótistnieją w jednej i tej samej Boskiej Istocie"s.

Mimo że zasługi Ojców Kapadockich w kształtowaniu się dogmatu trynitarnego są znaczące, Jan Paweł II - co ciekawe - jedynie kilkakrotnie odwołał się do ich nauczania. W cyklu „Bóg Ojciec”, podkreślając najpierw dokonania Soborów w Nicei (325) i w Konstantynopolu (381), wymienił następnie Kapadocczyków pośród kilku innych pisarzy wczesnochrześcijańskich w słowach:

„[...], trzeba także wspomnieć zasługi niektórych szczególnie zasłużonych teologów, zwłaszcza Ojców Kościoła: w okresie przednicejskim Tertuliana, Cypriana, Orygenesa, Ireneusza, w okresie nicejskim św. Atanazego i Efrema Syryjczyka, sprzed Soboru w Konstantynopolu - św. Bazylego Wielkiego oraz świętych Grzegorza z Nazjanzu i Grzegorza z Nyssy, Hilarego - aż po Ambrożego, Augustyna i Leona Wielkiego" .

W cykl katechez o Bogu Ojcu zostało także włączone nauczanie o aniołach, gdyż Bóg jest ich Stwórcą. Papież, zalecając modlitwę „Aniele Boży”, przywo-

${ }^{3}$ Jatmużna jest otwarciem się ku drugim 3 (28 III 1979), w: Nauczanie papieskie, II/1, Poznań 1990, 301; zob. Gregorius Nazianzenus, Oratio 14, 40, PG 35, 909D.

${ }^{4}$ Katechezy na temat Trójcy Świętej były wygłaszane od 5 grudnia 1984 do 3 lipca 1991 roku.

${ }^{5}$ Trzy Osoby Boże 1 (4 XII 1985), w: Katechezy Ojca Świętego Jana Pawła II. Bóg Ojciec, Kraków -Ząbki 1999, 118.

${ }^{6}$ Bóg Jedyny niewysłowioną i przenajświętsza Trójcą: Ojcem, Synem i Duchem Świętym 8 (9 X 1985), w: tamże, s. 102. 
łuje wypowiedź św. Bazylego, który wskazuje na anioła będącego u każdego wiernego wychowawcą i pasterzem: „Każdy wierny ma przy sobie anioła jako wychowawcę i pasterza, aby prowadził go do życia"7.

W drugim bloku trynitarnego nauczania Ojciec Święty zajął się Osobą Jezusa Chrystusa. Tam również pojawia się tzw. argument patrystyczny, czyli stwierdzenia pochodzące od Ojców Kościoła. Papież, omawiając definicje soborowe, zwraca uwagę na soteriologiczną rację, którą należało obronić w obliczu arianizmu i apolinaryzmu, gdzie zaprzeczano prawdziwemu człowieczeństwu Syna Bożego. Oryginalnym ujęciem tej soteriologicznej prawdy jest stwierdzenie Grzegorza z Nazjanzu o przyjęciu do jedności Syna całego człowieczeństwa, aby cały człowiek mógł być zbawiony, co papież przytoczył w wersji łacińskiej: „quod non est assumptum, non est sanatum”.

Inny tekst Grzegorza z Nazjanzu okazał się podstawą odniesienia papieskiej argumentacji w jednej z katechez cyklu o Duchu Świętym. Otóż według papieża samoobjawianie się Boga zawiera transcendentną pedagogię, polegającą na stopniowym objawianiu się tajemnicy Boskich Osób, które tworzą współistotną jedność. Na czym polegała ta pedagogia, Ojciec Święty wyjaśnia słowami jednej z mów Grzegorza:

„W rzeczywistości Stary Testament głosił otwarcie Ojca, a tylko niejasno wspominał o osobie Syna; Nowy Testament objawił Syna i wskazał na Boską istotę Ducha Świętego. Teraz Duch zamieszkuje w nas i Jego obecność ujawnia się wyraźniej. Byłoby bowiem nieroztropne jawnie głosić Syna, kiedy nie wyznawano jeszcze Boskości Ojca, i narzucać nam w dodatku - że się ośmielę w ten sposób wyrazić - Osobę Ducha Świętego, zanim została uznana Boskość Syna"9.

W tym samym cyklu został też dwukrotnie wymieniony Bazyli. Wprawdzie Jan Paweł II nie przytacza wprost jego słów, to jednak przypomina jego wielkie zasługi w wykładzie nauki o Duchu Świętym. Obok Ambrożego i Augustyna wymienia także ,innych Ojców i Doktorów łacińskich i greckich (począwszy od św. Hilarego, św. Bazylego, Pseudo-Dionizego Areopagity, św. Jana Damasceńskiego)" "10 którzy przygotowali formułę „od Ojca i Syna pochodzi” dotyczącą Ducha Świętego. Drugi raz w tej samej katechezie papież zwrócił uwagę na Bazylego w kontekście wykładu kwestii Filioque, mówiąc:

${ }^{7}$ Udziat aniołów $w$ dziejach zbawienia 7 (6 VIII 1986), w: tamże, s. 203; zob. Basilius, Adversus Eunomium III 1, PG 29, 655.

${ }^{8}$ Definicje soborowe (I) 10 (9 III 1988), w: Katechezy Ojca Świętego Jana Pawła II. Jezus Chrystus, Kraków - Ząbki 1999, 220; zob. Gregorius Nazianzenus, Epistula 101 (Ad Cledonium), PG 37, 181C.

9 Boska pedagogia w objawieniu Osoby Ducha Świętego 1 (22 VIII 1990), w: Katechezy Ojca Świętego Jana Pawła II. Duch Swięty, Kraków - Ząbki 1999, 189; zob. Gregorius Nazianzenus, Oratio 31, 26, PG 36, 161.

10 Duch, który od Ojca i Syna pochodzi 5 (7 XI 1990), w: tamże, s. 219. 
„Nie brak konkretnych podstaw dla tej doktryny w pismach wielkich Ojców i Doktorów Wschodu (Efrem, Atanazy, Bazyli, Epifaniusz, Cyryl Aleksandryjski, Maksym, Jan Damasceński) i Zachodu (Tertulian, Hilary, Ambroży, Augustyn)" "11.

Trzeba przyznać, że w odniesieniu do Ojców Kapadockich katechezy na temat Trójcy Świętej zawierają bardzo nieliczne wzmianki pochodzące z ich twórczości, zwłaszcza że w kwestiach trynitarnych okazali się twórcami trafnych i oryginalnych stwierdzeń.

Następny cykl katechez, który dotyczył Kościoła ${ }^{12}$, nie zawiera odniesień do Ojców Kapadockich. Pojawiają się one dopiero w kolejnym cyklu, który Jan Paweł II poświęcił Maryi ${ }^{13}$, gdzie są dwie wzmianki odnoszące się do ich twórczości. Grzegorz z Nyssy został przywołany z tego względu, że stosował do Maryi tytuł „Matka życia”14. Natomiast z nauczania Grzegorza z Nazjanzu papież zaczerpnął myśl na temat świętości Maryi i jej oczyszczenia:

„Ojcowie greccy i wschodni uznawali fakt, że łaska dokonała oczyszczenia w Maryi zarówno przed wcieleniem, jak i w samym momencie wcielenia (św. Efrem, Sewerian z Gabali, Jakub z Sarug)"15.

Pierwsza część tej wypowiedzi jest streszczeniem nauki Grzegorza z Nazjanzu. Jubileuszowy Rok 2000 stał się kanwą następnego cyklu katechez ${ }^{16}$, w których Ojciec Święty przedstawił program duchowy w oparciu o fakt narodzenia, tj. Wcielenia Syna Bożego. Temu zbawczemu wydarzeniu papież nadał wymiar trynitarny, nawiązując do ogłoszonego już 10 listopada 1994 r. Listu Apostolskiego Tertio millenio adveniente, w którym zapowiedział przygotowawczą fazę do obchodu Jubileuszowego Roku trwającą trzy lata, tj. od 1997 do 1999 r., poświęconych kolejno Jezusowi Chrystusowi, Duchowi Świętemu i Bogu Ojcu. W katechezach z tego okresu papież oddawał kilkakrotnie głos także Kapadocczykom Bazylemu Wielkiemu, nauczającemu o utracie przez diabła mocy w obecności Ducha Świętego („diabeł stracił swoją moc w obliczu obecności Ducha Świętego" $)^{17}$, towarzyszącemu we wszystkim Jezusowi (,nieodłącznym towarzyszem we wszystkim" ${ }^{18}$ i obecnemu przy ostatecznym przejściu nas do Ojca:

11 Tamże 6, s. 219.

12 Wygłaszane były od 10 lipca 1991 do 30 sierpnia 1995 roku.

13 Jan Paweł II wygłaszał je od 6 września 1995 do 12 listopada 1997 roku.

14 Udziat Maryi w dziele zbawienia 5 (25 X 1995), w: Katechezy Ojca Świętego Jana Pawta II. Maryja, Kraków - Ząbki 1999, 14.

15 Doskonała świętość Maryi 3 (15 V 1996), w: tamże, s. 65; zob. Gregorius Nazianzenus, Oratio 38, 16, PG 36, 329-330.

16 Były głoszone od 19 listopada 1997 do 12 stycznia 2000 roku.

17 Duch Święty podczas chrztu i w życiu publicznym Chrystusa 3 (3 VI 1998), w: W drodze do Roku 2000. Katechezy papieskie, Częstochowa 1999, 98; zob. Basilius, De Spiritu Sancto 19, 49, PG $32,157 \mathrm{~A}$.

18 Tajemnica paschalna fundamentem daru Ducha Świętego 1 (10 VI 1998), w: tamże, s. 103; zob. Basilius, De Spiritu Sancto 16,39, PG 32, 140C. 
„Jeżeli ktoś zastanowi się uważnie, to zrozumie, że również w chwili oczekiwania na objawienie Pana z niebios Duch Święty nie odstąpi, jak niektórzy sądzą; On bowiem będzie obecny również w dniu ukazania się Pana, kiedy On, błogosławiony i jedyny Pan, będzie sądził świat sprawiedliwie" 19 .

Wydarzenie Wcielenia Syna Bożego łączy się ściśle z obecnością w tym fakcie Ducha Świętego. Katechezy wyjaśniające te prawdy odwołują się zatem do Bazylego, wielkiego autorytetu IV wieku, który jako pierwszy napisał specjalny traktat o Duchu Świętym.

Papież z uznaniem odniósł się także do Grzegorza z Nyssy, który nauczał o Duchu Świętym będącym węzłem pokoju podczas ziemskiej pielgrzymki prowadzącej do kosztowania uczty wiecznej. Oto jego słowa:

„Otoczeni jednością Ducha Świętego, jako węzłem pokoju, wszyscy będą jednym Ciałem i jednym Duchem"20.

Myśl Grzegorza z Nyssy posłużyła Ojcu Świętemu do wyjaśnienia szczególnego doświadczenia człowieka, jakim jest poznanie Boga Ojca:

„Jest to poznanie pozwalające «spotkać» Boga poprzez uczestnictwo w procesie, który wschodnia tradycja nazywa «przebóstwieniem» i które dokonuje się dzięki wewnętrznemu i przemieniającemu działaniu Bożego Ducha”"21.

Swoistym podsumowaniem nauczania o Trzech Boskich Osobach w latach poprzedzających Rok Jubileuszowy jest cykl katechez o Trójcy Świętej wygłaszany w roku $2000^{22}$. Aby w jakimś stopniu przybliżyć się do tajemnicy Trójcy Świętej, papież zachęca wiernych do pójścia drogą Grzegorza z Nazjanzu nazwanego „Teologiem” z uwagi na dojrzały wykład nauki o Boskich Osobach. Jedna z wielu jego cytowanych wypowiedzi na ten temat jest następująca:

„Chwała Bogu Ojcu i Synowi, Królowi wszechświata. Chwała Duchowi Świętemu. Godnemu chwały i w pełni świętemu. Trójca Święta jest jednym Bogiem, który stworzył i napełnił każdą rzecz [...], ożywiając każdą rzecz swym Duchem, aby każde stworzenie wychwalało swego mądrego Stwórcę, jedynego sprawcę życia i trwania. Bardziej zaś niż wszelkie inne stworzenia, niech stworzenie rozumne sławi Go zawsze jako wielkiego Króla i dobrego Ojca"²3.

Bez wątpienia Grzegorz z Nazjanzu był autorytetem w tym względzie.

19 Duch „Ożywiciel” a zwycięstwo nad śmiercią 5 (28 X 1998), w: tamże, s. 191; zob. Basilius, De Spiritu Sancto 16, 40, PG 32, 68.

${ }^{20}$ Duch Święty duszą Kościoła 5 (8 VII 1998), w: tamże, s. 122; zob. Gregorius Nyssenus, Homiliae in Canticum Canticorum 15, PG 44, 1110.

21 «Poznać» Ojca 1 (17 III 1999), OsRomPol 20 (1999) nr 7, s. 46-47; zob. Gregorius Nyssenus, Oratio catechetica 37, PG 45, 98B.

22 Katechezy na temat Trójcy Świętej Jan Paweł II wygłaszał od 19 stycznia 2000 do 20 września 2000 roku.

${ }^{23}$ Chwata Trójcy Świętej w dziejach 5 (9 II 2000), w: OsRomPol 21 (2000) nr 7-8, s. 44; zob. Gregorius Nazianzenus, Poemata dogmatica hymnus 21, PG 37, 510-511. 
Wskazując na obecność Ducha Świętego w dziejach Kościoła i w każdym chrześcijaninie, papież odwołuje się do Bazylego Wielkiego, który nauczał, że Duch Święty „rozchodzi się po wszystkich nie pomniejszając się, obecny jest w każdym - tak jakby tylko o niego chodziło - spośród tych, którzy są zdolni Go przyjąć, i wszystkim udziela wystarczającej i pełnej łaski"24. Przytoczona myśl tego Ojca Kościoła jest bardzo istotna dla zrozumienia kondycji duchowej poszczególnego wyznawcy Chrystusa i jego miejsca w społeczności kościelnej.

W Roku Jubileuszowym, odnoszącym się w przede wszystkim do tajemnicy Wcielenia, papież Jan Paweł II podjął się wygłoszenia nauk - wynikających z tego faktu - na różne tematy wiążące się z życiem wspólnoty chrześcijańskiej. Na pierwszym miejscu postawił Eucharystię, następnie dialog ekumeniczny, po czym zajął się pojedynczymi zagadnieniami dotyczącymi codziennego życia chrześcijan $^{25}$. Wśród tych ostatnich sprawą ważną dla Ojca Świętego okazała się także kwesta ekologii na obecnym etapie ludzkiej cywilizacji. Następca Piotra w katechezie temu poświęconej odwołuje się do Biblii, zwłaszcza do II rozdz. Księgi Rodzaju. W swój komentarz, wyjaśniający harmonię człowieka z bliźnimi, ze stworzeniem i z Bogiem, włącza także refleksję Grzegorza z Nyssy, który w swej twórczości często podejmował wątki obecności człowieka w świecie. Oto jego głos w tej materii:

„Bóg uczynił człowieka w taki sposób, aby mógł on sprawować swą funkcję króla ziemi, [...] Człowiek został stworzony na podobieństwo Tego, który rządzi wszechświatem. Wszystko to wskazuje, że od samego początku jego natura nosi znamię królewskości. [...] Jest on żywym obrazem, który przez swoją godność uczestniczy w doskonałości Boskiego wzoru"26.

Niewątpliwie myśl tego Kapadocczyka trafnie komentuje wskazania moralne z zakresu bioetyki podane przez papieża.

Po wygłoszeniu katechez o różnej tematyce dotyczącej bieżących i jednocześnie ważnych zagadnień życia chrześcijańskiego Jan Paweł II podjął kolejny cykl, który oparł na Psalmach ${ }^{27}$. Ich komentowanie wspierał myślami zaczerpniętymi z tekstów pisarzy wczesnochrześcijańskich, w tym także Ojców Kapadockich. Papież dał temu wyraz w katechezie na temat pieśni z Księgi Izajasza, gdy w sposób ogólny do nich się odwołał, mówiąc: „Ojcowie Kościoła z IV i V

${ }^{24}$ Chrześcijanin ożywiany Duchem 1 (13 IX 2000), OsRomPol 22 (2001) nr 1, s. 41; zob. Basilius, De Spiritu Sancto 9, 22, PG 32, 109A.

${ }^{25}$ Katechezy na tematy związane z różnymi sprawami życia chrześcijańskiego były wygłaszane od 27 września 2000 do 1 sierpnia 2001 roku.

${ }^{26}$ Trzeba zapobiec katastrofie ekologicznej 2 (17 I 2001), OsRomPol 22 (2001) nr 4, s. 43; zob. Gregorius Nyssenus, De hominis opificio 4, PG 44, 136.

${ }^{27}$ Katechezy w oparciu o Psalmy wygłaszane były od 8 sierpnia 2001 do 26 stycznia 2005 roku. 
wieku (Bazyli Wielki, Jan Chryzostom, Teodoret z Cyru, Cyryl Aleksandryjski) widzieli jej spełnienie w przyjściu Chrystusa" 28 .

Tego typu odwołanie się do Ojców znajduje się w katechezie dotyczącej Psalmu 51 [50], w którym papież nauczając o roli Ducha Świętego, przywołuje Ambrożego, po czym dodaje:

„Podobne przekonanie wyrażają inni Ojcowie, jak Dydym Ślepy z egipskiej Aleksandrii oraz Bazyli z Cezarei, w swoich traktatach o Duchu Świętym"29.

Podobna sytuacja ma miejsce w katechezie omawiającej pieśń z Księgi Daniela, gdzie w zakończeniu papież powiedział:

„Zakończmy nasze rozważanie oddając głos Ojcom Kościoła - takim jak Orygenes, Hipolit, Bazyli z Cezarei czy Ambroży z Mediolanu - którzy komentowali przekaz o sześciu dniach stworzenia właśnie w kontekście Pieśni trzech młodzieńców”30.

Ponadto Jan Paweł II korzystał z dosłownych cytatów Bazylego. Tekst wyjęty ze wspomnianego jego komentarza do sześciu dni stworzenia posłużył papieżowi w wyjaśnianiu hymnu na cześć Stwórcy, którym jest Psalm 148. W katechezie na temat tego psalmu pojawiają się następujące słowa:

„Nawet głębią nie pogardzał psalmista, który przyjął ją do powszechnego chóru stworzenia; co więcej, również i ona swoim własnym językiem dopełnia harmonijnie hymn na cześć Stwórcy"31.

Kolejne cytaty z dzieł Bazylego zostały użyte przez papieża w katechezach, które poświęcił liturgii Jutrzni i Nieszporów. Omawiając Jutrznię w oparciu o Psalm 101 [100], następca Piotra poucza, by w czasie tej modlitwy unikać wszelkich negatywnych myśli. Swoje pouczenie wspiera wskazówką Bazylego, który okazał się mistrzem duchowym, tworząc szereg dzieł ascetycznych. $\mathrm{Z}$ jednego $\mathrm{z}$ nich pochodzą te słowa:

„Nawet chwilowa przyjemność, zanieczyszczająca myśl, nie powinna dosięgnąć tego, który przyłączony jest do Chrystusa przez śmierć podobną do Jego" ${ }^{32}$.

Na początku dnia dusza chrześcijanina musi więc być oczyszczona od hedonistycznych podniet. Natomiast wieczór to chwila „podziękowania za to, co zos-

28 Pieśn Iz 2, 2-5 - świątynia Pańska światłościa narodów 4 (4 IX 2002), OsRomPol 23 (2002) nr 12 , s. 32.

${ }^{29}$ Psalm 51 - błaganie grzesznika 2 (4 XII 2002), OsRomPol 24 (2003) nr 3, s. 33.

${ }^{30}$ Pieśń Dn 3, 57-88. 56 - całe stworzenie wielbi Boga 5 (10 VII 2002), OsRomPol 23 (2002) nr 10-11, s. 48.

31 Psalm 148 - hymn na cześć Stwórcy 2 (17 VII 2002), OsRomPol 23 (2002) nr 10-11, s. 49; zob. Basilius, In Hexaemeron hom. III 9, PG 29, 75.

32 Psalm 101 - wyznanie żarliwej duszy 2 (30 IV 2003), OsRomPol 24 (2003) nr 10, s. 47; zob. Basilio, Opere ascetiche, Torino 1980, 548. 
tało nam ofiarowane lub czego dokonaliśmy w prawości”33. Tymi słowami Bazylego wspomaga swe wskazania papież, który w innej katechezie wyjaśniał liturgię Nieszporów.

Na kanwie Psalmu 29 [28] papież objaśnia znaczenie siedmiu grzmotów będących głosem Boga we wszechświecie. W teofanii przy chrzcie Jezusa słowa o umiłowanym Synu (Mk 1,11) są tego najwznioślejszą wypowiedzią. Ten moment historii zbawienia Ojciec Święty pozwolił wyjaśnić Bazylemu Wielkiemu w słowach:

„W bardziej mistycznym sensie «głos Pana nad wodami» zabrzmiał może wtedy, gdy podczas chrztu Jezusa z wysoka dały się słyszeć słowa: To jest mój Syn umiłowany. Wówczas rzeczywiście Pan unosił się nad rozległym obszarem wód, uświęcając je przez chrzest. Bóg chwały grzmiał z wysoka donośnym głosem swego świadectwa [...]. Możesz też zrozumieć, że «grzmot» oznacza ową przemianę, jaka po chrzcie dokonuje się za sprawą wielkiego «głosu» Ewangelii" ${ }^{34}$.

Interpretacja zaproponowana przez Bazylego ujęta została - jak sam podaje w sensie mistycznym. Taki sam sposób podejścia do tekstu biblijnego widoczny jest w innej wypowiedzi Bazylego, którą Jan Paweł II cytuje w celu wyjaśnienia tzw. pieśni nowej, zawartej w jednym z wersetów Psalmu 33 [32]:

„Zazwyczaj nazywamy «nowym» coś, co jest niezwykłe lub co niedawno powstało. Gdy zastanawiasz się, w jak zadziwiający i przechodzący najśmielsze wyobrażenie sposób doszło do wcielenia się Pana, z ust twoich płynie pieśń nowa i niezwykła. I jeśli w myśli odtwarzasz proces odrodzenia i odnowy całej ludzkości, postarzałej na skutek grzechu, i głosisz tajemnice zmartwychwstania, również wtedy śpiewasz pieśń nową i niezwykłą"35.

Należy ponadto zauważyć u Bazylego umiejętność polegającą na łączeniu treści Starego Testamentu z faktami Nowego - w tym przypadku z tajemnicą zmartwychwstania, czyli wypełnienia się wszystkiego w Chrystusie. Papież, skupiając się w swej katechezie przede wszystkim na Bożej Opatrzności, za swego przewodnika w dalszej jej części obrał znowu Bazylego, którego zacytował jeszcze dwa razy. Prawdę, że Bóg jest Panem ludzkich dziejów, Ojciec Święty uzupełnia taką wypowiedzią Kapadocczyka:

„Gdziekolwiek się udajesz, cokolwiek czynisz, zarówno w mroku, jak i w świetle dnia, spogląda na ciebie oko Boże" ${ }^{36}$.

${ }^{33}$ Wprowadzenie do liturgii Nieszporów 1 (8 X 2003), OsRomPol 25 (2004) nr 3, s. 38; zob. Basilius, Regulae fusius tractatae 37, 3, PG 3, 1015.

${ }^{34}$ Pan ogłasza z moca swe stowo 5 (13 VI 2001), OsRomPol 22 (2001) nr 10, s. 19; zob. Basilius, Homiliae in Psalmos 33, 4, PG 29, 360.

${ }^{35}$ Psalm 33 - hymn ku czci Bożej Opatrzności 1 (8 VIII 2001), OsRomPol 22 (2001) nr 10, s. 23; zob. Basilius, Homiliae in Psalmos 33, 2, PG 29, 327.

${ }^{36}$ Tamże 3, s. 24; zob. Basilius, Homiliae in Psalmos 33, 8, PG 29, 343. 
Boża Opatrzność polega na stałym pochylaniu się nad bezsilną ludzkością, w zamian czego Bóg oczekuje wiary i pokory. Ten aspekt dostrzegł Bazyli, na którego powołuje się papież:

„Pokora tych, którzy służą Bogu pokazuje, jak ufają oni Jego miłosierdziu. Kto bowiem nie liczy na własne wielkie dzieła ani nie oczekuje usprawiedliwienia ze względu na swe czyny, pokłada jedyną nadzieję zbawienia w Bożym miłosierdziu" ${ }^{37}$.

Należy stwierdzić, że treść poszczególnych tekstów wyjętych z twórczości Bazylego jest bardzo różnorodna, tzn. że ten Ojciec Kościoła wypowiadający się na wielu płaszczyznach ówczesnej teologii okazał się autorytetem i ważnym świadkiem wiary dla Jana Pawła II.

W cyklu katechez obejmującym Psalmy nie brak Grzegorza z Nazjanzu wybitnego znawcy teologii trynitarnej, czego świadectwem były jego myśli wyżej już cytowane. Jan Paweł II powtórnie wraca do teologicznej mądrości tego Kapadocczyka, korzystając z tych tekstów, które zawierają chwałę i uwielbienie Osób Boskich. Psalm 93 [92] - podkreślający wspaniałość Boga Stworzyciela - będący przedmiotem nauczania papieża, kończy się długim cytatem fragmentu jednej z pieśni Grzegorza:

„Ty, [Ojcze], stworzyłeś wszechświat, wyznaczając każdej rzeczy przysługujące jej
miejsce i podtrzymując ją dzięki Twej opatrzności [...]. Twe Słowo jest Bogiem-
Synem: jest bowiem współistotne Ojcu, równe Mu w czci. Zjednoczył On harmonij-
nie wszechświat, by nad wszystkim zakrólować. A Duch Swięty, Bóg, obejmując
wszystko, troszczy się o każdą rzecz i ją chroni. Będę sławił Cię, żywa Trójco, jedyny
Monarcho, [...] niewzruszona mocy podtrzymująca niebiosa, spojrzenie niedostępne
dla wzroku, lecz kontemplujące cały wszechświat i znające wszelkie tajemne gębie
aż po otchłanie. O Ojcze, bądź łaskawy: [...] obym mógł znaleźć miłosierdzie i łaskę,
ponieważ Tobie należy się chwała i łaska na wieki bez końca" ${ }^{38}$.

Tak długi tekst został przytoczony przez papieża nie bez powodu: pochwała rzeczy stworzonych w kontekście uwielbienia Boga Trójjedynego i wypowiedzenia każdej z Boskich Osób należnej czci wymagała dłuższej wypowiedzi. Jan Paweł II w głoszonej katechezie osobiście oddał hołd Trójcy, posługując się głęboko teologicznym tekstem kapadockiego poety.

Podobny hołd uwielbienia Trójcy Świętej słowami Grzegorza z Nazjanzu papież złożył w katechezie omawiającej pieśń z Apokalipsy. Również tam nie mógł się oprzeć skróceniu poetycko ujętej czci skierowanej ku Bogu Trójjedynemu:

„Chwała Ojcu i Synowi, Królowi wszechświata, chwała Najświętszemu Duchowi, któremu należna jest wszelka chwała. Jedyny Bóg jest Trójcą: On stworzył i na-

37 Tamże 4, s. 24; zob. Basilius, Homiliae in Psalmos 33, 10, PG 29, 347.

38 Psalm 93 - wspaniałość Boga Stworzyciela 5 (3 VII 2002), OsRomPol 23 (2002) nr 10-11, s. 47; zob. Gregorius Nazianzenus, Carmina 31, PG 37, 511-512, ed. Poesie/1 Roma 1994, s. 65-66. 
pełnił wszystko, niebiosa istotami niebieskimi, a ziemię istotami ziemskimi. Morza, rzeki i źródła napełnił istotami wodnymi, wszystko ożywiając swoim Duchem, aby całe stworzenie wychwalało mądrego Stwórcę: On jest jedyną przyczyną życia i trwania przy życiu. Niechaj zwłaszcza rozumna natura wyśpiewuje Jego chwałę jako potężnego Króla i dobrego Ojca. Spraw, Panie, bym w duchu, całym wnętrzem, językiem i myślą również i ja w czystości wychwalał Ciebie, o Ojcze”39.

Obydwa teksty wprawdzie stanowią hymn uwielbienia dla Boga Stwórcy, Grzegorz - przejęty wówczas właściwym orzekaniem o Trzech Boskich Osobach - nie mógł nie ująć swych przemyśleń w kontekście trynitarnym. Wypowiedział więc bardzo ważne stwierdzenia o charakterze orzeczeń teologicznych, które po czasie okazały się bardzo trafnymi określeniami.

Oprócz wypowiedzi ściśle trynitarnych Grzegorz z Nazjanzu zabierał głos odnoszący się także do problematyki chrystologicznej. Naukę z tej materii także dostrzegł Jan Paweł II, przytaczając jeden z najpiękniejszych opisów, pochodzących ze starożytności chrześcijańskiej, przedstawiający tajemnicę Wcielenia Chrystusa w kazaniu na Boże Narodzenie. Fragment tego kazania papież wykorzystał dla ukazania teologii Psalmu 96 [95]:

„Rodzi się Chrystus - oddawajcie Mu chwałę! Chrystus zstępuje z niebios - wyjdźcie Mu naprzeciw! Chrystus jest na ziemi - powstańcie! «Spiewaj Panu, ziemio cała» $\mathrm{i}$ - aby zespolić oba pojęcia - «niech się radują niebiosa i ziemia weseli» z powodu Tego, który jest niebieski, ale potem stał się ziemski" ${ }^{40}$.

Grzegorz w tok swych sentencji o przychodzącym na ziemię Chrystusie wplótł także wyrażenia z Psalmu 96 (co zostało w cytacie zaznaczone). Z tego też powodu fragment ten znalazł się w katechezie omawiającej ten psalm.

W środowych katechezach Jan Paweł II korzystał także z zapisów Grzegorza z Nyssy. Analizując Psalm 57 [56], w którym zajmuje się modlitwą poranną człowieka cierpiącego, odwołuje się do stwierdzeń tego Ojca kapadockiego w odniesieniu do doświadczeń człowieka uznającego Bożą mądrość:

„Zbawił mnie bowiem otaczając mnie cieniem obłoku Ducha, a ci, którzy mnie maltretowali, zostali poniżeni" ${ }^{41}$.

Grzegorz z Nyssy pomaga komentować refleksje papieża w katechezach na temat innych Psalmów. Tak oto przy interpretowaniu Psalmu 117 [116] papież zapożyczył od Kapadocczyka wyrażenie „dobry dwumian”42 na określenie

${ }^{39}$ Pieśń Ap 15, 3-4 - hymn uwielbienia 4 (23 VI 2004), OsRomPol 25 (2004) nr 9, s. 22; zob. Gregorius Nazianzenus, Carmina dogmatica hymnus 31, PG 37, 510-511.

40 Psalm 96 - śpiewajcie Panu pieśń nowa 5 (18 IX 2002), OsRomPol 23 (2002) nr 12, s. 33; zob. Gregorius Nazianzenus, Oratio 38, 1, PG 36, 312A.

${ }^{41}$ Psalm 57 - poranna modlitwa w cierpieniu 6 (19 IX 2001), OsRomPol 23 (2002) nr 2, s. 49; zob. Gregorius Nyssenus, In Psalmorum inscriptiones, Roma 1994, 183.

42 Psalm 117 - zachęta do wielbienia Boga za Jego miłość 3 (28 XI 2001), OsRomPol 23 (2002) nr 4, s. 42-43; zob. Gregorius Nyssenus, In Psalmorum inscriptiones, Roma1994, 183. 
dwóch cnót Bożego oblicza, którymi są hésed (splot pozytywnych uczuć) i emét (prawda).

Natomiast o wiele dłuższy tekst Grzegorza z Nyssy Ojciec Święty przytoczył w katechezie zawierającej analizę pieśni z Księgi Daniela. Przedmiotem uwielbienia tej pieśni jest chwalenie Pana przez każde stworzenie. Następujące słowa Nysseńczyka stanowią ciąg dalszy papieskiego nauczania:
„Podobnie jak ten, kto spogląda na świat materialny, wnioskuje na podstawie rzeczy widzialnych o pięknie niewidzialnym [...], tak i ten, kto spogląda na nowy świat eklezjalnego stworzenia, dostrzega w nim Tego, który stał się wszystkim we wszystkich, prowadząc «za rękę» nasz umysł za pośrednictwem rzeczy zrozumia- łych dla naszej rozumnej natury ku temu, co przekracza ludzkie pojmowanie",43.

Autor wyraża więc pochwałę świata stworzonego przez Boga, jak i uczynionej przez Niego wspólnoty kościelnej, gromadzącej się w Dniu Pańskim, by co tydzień wyśpiewać tę pieśń.

Uwielbienie dla Stwórcy powinno także mieć miejsce - według Jana Pawła II w katechezie na temat pieśni z Księgi Izajasza - u początku każdego dnia, do czego zachęcany jest wierny w liturgii Jutrzni. Głębię tego uwielbienia papież wyraził słowami Grzegorza z Nyssy, który do wspomnianej pieśni pozostawił taki komentarz:
„Kiedy słyszymy słowo «wszechmocny», myślimy o tym, że Bóg podtrzymuje w ist- nieniu wszystkie rzeczy, zarówno te, które są wytworem myśli, jak i te, które należą do stworzenia materialnego. $\mathrm{Z}$ tego bowiem powodu On zamyka okrąg ziemski, dlatego ma w swym ręku krańce ziemi, dlatego w Jego dłoni mieści się niebo, dlatego mierzy wodę ręką, dlatego zawiera w sobie całe myślące stworzenie: aby wszystkie rzeczy trwały w istnieniu, utrzymywane z mocą przez moc, która je scala" ${ }^{44}$.

Poszczególne wątki tego tekstu, stanowiące treść codziennej modlitwy, mają ponadto kosmologiczny charakter z powodu filozoficznego podejścia Nysseńczyka do otaczającej rzeczywistości.

Natomiast katecheza Jana Pawła II dotycząca Psalmu 115 [113B] przenosi myśl słuchacza ku modlitwie wieczornej, gdyż ten psalm należy do liturgii Nieszporów. W passusie papieskiego nauczania, w którym jest mowa o przemianie ludzkiego ducha, został przywołany Grzegorz z Nyssy, przekazujący na ten temat następujące refleksje:

„Jak bowiem ci, którzy wpatrują się w prawdziwego Boga, zyskują szczególne znamiona Boskiej natury, tak i ten, co hołduje próżności bożków, przemienił się

43 Pieśn Dn 3, $52-57$ - niech wszelkie stworzenie wielbi Pana 5 (12 XII 2001), OsRomPol 23 (2002) nr 4, s. 45; zob. Gregorius Nyssenus, In Canticum Canticorum oratio 13, GNO VI 1-22, s. 385.

44 Pieśn Iz 40, 10-17 - dobroć i wielkość Boga 5 (20 XI 2002), OsRomPol 24 (2003) nr 3, s. 32; zob. Gregorius Nyssenus, Teologia trynitaria, Milano 1994, 625. 
w istotę podobną do tego, w co się wpatrywał, i z człowieka stał się skałą. Dlatego więc, gdy naturę ludzką bałwochwalstwo zmieniło w skałę obojętną na lepsze rzeczy, stężałą w kulcie bożków, nad tą straszliwą zimą wschodzi Słońce sprawiedliwości i niesie wiosnę lekki południowy wiatr, który roztapia szron, a promienie słoneczne ogrzewają wszystko, co jest ponad nim; i w ten sposób człowiek, którego mróz zamienił w skałę, rozgrzany przez Ducha i promień Logosu, na nowo stał się wodą tryskającą, by osiągnąć życie wieczne"45.

Jak podaje treść papieskiej katechezy, kapadocki Ojciec w swej homilii nawiązuje do Psalmu 115, opisując przejście ludzkości od straszliwej zimy bałwochwalstwa do wiosny zbawienia.

\section{OJCOWIE KAPADOCCY W HOMILIACH PAPIESKICH}

Do zwyczajnych obowiązków papieża, a jednocześnie biskupa Rzymu, należy wygłaszanie homilii w niedziele $\mathrm{i}$ święta oraz podczas innych uroczystości w bazylice św. Piotra i w kościołach rzymskich. Jest to obowiązek wynikający nie tylko z przyjętych święceń kapłańskich i biskupich, ale także ze szczególnego posłannictwa, jakie pełni następca św. Piotra.

Homilie papieskie są okazją do zgłębienia prawd wiary podanych przez teksty czytań biblijnych z jednoczesnym powiązaniem z bieżącymi okolicznościami życia chrześcijańskiego. W czasie ich wygłaszania Jan Paweł II sięgał też do tradycji Ojców Kościoła, w tym tylko jeden raz do Ojców Kapadockich. W homilii wygłoszonej w jednej z rzymskich parafii papież, wyjaśniając symbolikę białej szaty w obrzędzie chrztu, nawiązał do słów Grzegorza z Nyssy, który wskazał na „szatę niezniszczalną ofiarowaną przez Chrystusa” ${ }^{46}$.

\section{OJCOWIE KAPADOCCY W PRZEMÓWIENIACH PAPIESKICH}

Szczególnym rodzajem nauczania papieskiego są przemówienia kierowane do różnych grup wiernych w czasie audiencji prywatnych. Specyfika ich zawartości treściowej oscyluje między oficjalnymi wystąpieniami, np. do korpusu dyplomatycznego, a ojcowskimi wskazówkami adresowanymi np. do zakonnic i zakonników. Zdarzało się, że Jan Paweł II w tego typu przemówieniach przytaczał, obok innych ważnych dokumentów, także myśli Ojców Kościoła, w tym również Kapadocczyków.

45 Psalm 115 - chwała prawdziwego Boga 4 (1 IX 2004), OsRomPol 26 (2005) nr 1, s. 42; zob. Gregorius Nyssenus, Homiliae in Canticum Canticorum V, Roma 1988, 133-134.

${ }^{46}$ Homilia wygłoszona w parafii świętych Aniołów Strózów na Monte Sacro: Chrystus niech będzie treścią waszego życia 1 (6 IV 1986), w: Nauczanie papieskie, IX/1, Poznań 2005, s. 469; zob. Gregorius Nyssenus, De baptismo, PG 46, 420C. 
Pielgrzymami o szczególnym znaczeniu dla Jana Pawła II byli biskupi składający wizytę ad limina Apostolorum. Papież w przemówieniu do grupy biskupów Patriarchatu antiocheńskiego obrządku melchickiego na czele z Maksimosem V wyraził swe zadowolenie i zachęcił ich „,do kontynuowania tej dobrej pracy duszpasterskiej, według wzoru naszego Pana Jezusa i według częstych wskazań Ojców Kościoła Wschodniego, a szczególnie św. Bazylego Wielkiego" 47 .

Jan Paweł II przemawiał w sposób regularny do pracowników poszczególnych stopni Kurii Rzymskiej oraz papieskich placówek z nią współpracujących. I tak, uczestnicy sesji plenarnej Papieskiej Akademii Nauk w kierowanym do nich wystąpieniu mieli możliwość usłyszenia stwierdzenia z nauczania Grzegorza z Nazjanzu o Chrystusie, który przyjął ludzką naturę:

„To właśnie miał na myśli Grzegorz z Nazjanzu, gdy mówił o Chrystusie, który przyjął naszą ludzką naturę: "Chrystus posługuje się podobnym, aby uzdrowić podobne». Według wizji tego Ojca kapadockiego podejście metafizyczne i ontologiczne pozwala nam pojąć tajemnicę wcielenia i odkupienia"48.

Inną okazją do przywołania świadków tradycji było spotkanie papieża z przedstawicielami Chrześcijańskiego Ośrodka dla Osób Niepełnosprawnych, który w 2003 r. obchodził 40-lecie powstania. Jan Paweł II nawiązał wówczas do stwierdzenia Grzegorza z Nazjanzu: mówiąc o służbie wobec bliźnich, wyraził podziękowanie, zwłaszcza za „posługę miłości, z życzliwością i współczuciem dla niepełnosprawnych i ich rodzin, które «przyoblekły się w oblicze Chrystusa», jak mówi św. Grzegorz z Nazjanzu"49.

$$
* * *
$$

Dokonując podsumowania powyższych rozważań, należy uświadomić sobie, że liczba pisarzy wczesnochrześcijańskich przywoływanych przez Jana Pawła II jest stosunkowo duża. Stąd też skarbiec spuścizny patrystycznej, przed jakim stanął Jan Paweł II, jest przebogaty w przemyślenia o charakterze teologicznym, moralnym czy ascetycznym. Papież miał więc do dyspozycji ogromną ilość tekstów wielu autorów. Jak się okazuje, Ojców Kapadockich

47 Przemówienie do biskupów obrządku melchickiego: Wyrażenie zadowolenia z działalności Patriarchatu i Synodu (13 X 1980), w: Nauczanie papieskie III/2, Poznań 1986, 468; zob. Basilius, Regulae morales 80, 12-21, PG 31, 864B-868B.

48 Przemówienie do uczestników sesji plenarnej Papieskiej Akademii Nauk: Aby głębiej zrozumieć tajemnicę Boga, czlowieka i stworzenia 5 (27 X 1998), OsRomPol 20 (1999) nr 2, s. 49; zob. Gregorius Nazianzenus, Oratio 38, 13, PG 36, 325.

49 Przemówienie do przedstawicieli Chrześcijańskiego Ośrodka dla Osób Niepełnosprawnych z Paryża: Szacunek dla życia najsłabszych 2 (13 XI 2004), OsRomPol 26 (2005) nr 2, s. 40; zob. Gregorius Nazianzenus, Oratio 14, 14, PG 35, 876. 
przywoływał 42 razy: Bazylego Wielkiego - 19 razy, Grzegorza z Nazjanzu 11 razy i Grzegorza z Nyssy - 12 razy (o ile nie pojawiły się pominięcia wypowiedzi tych Ojców podczas przeglądania przez autora tego artykułu wiele setek stron wydanych przez różnych wydawców). Biorąc pod uwagę kryterium postawione na początku artykułu dotyczące tego, że brane pod uwagę będą jedynie publiczne wystąpienia papieża na terenie Watykanu i Rzymu, należy zauważyć, że układ poszczególnych odniesień do Ojców Kapadockich w tych wystąpieniach jest rozłożony nierównomiernie. Podczas przemówień na „Anioł Pański" pojawiły się jedynie dwa odniesienia, w homiliach zaledwie jedno, w przemówieniach okolicznościowych tylko trzy. Największa ilość wypowiedzi Kapadocczyków występuje w katechezach środowych, bo aż 36 razy. Jest to $\mathrm{z}$ tego względu oczywiste, że charakter nauczania papieskiego w tego typu wystąpieniach zbliżony jest do działalności nauczycielskiej Ojców Kościoła. Zarówno bowiem pasterze pierwszych wieków, jak i arcypasterz naszych czasów, Jan Paweł II, zajmowali się tą samą tematyką, poruszali te same zagadnienia odnoszące się do wiary i moralności czy też podawali interpretację tego samego Pisma Świętego. Przywoływanie po tylu wiekach wypowiedzi świadków Tradycji przez Jana Pawła II oznacza eklezjalną łączność z ówczesnymi wspólnotami chrześcijańskimi. Stwierdzenia bezpośrednich następców epoki apostolskiej stają się nieodzownym argumentem teologicznym dla przekazu kerygmatu przez papieża dzisiaj.

\section{PATRES CAPPADOCIAE DE IOANNI PAULI II DOCTRINA}

\section{(Argumentum)}

Continet hoc opusculum verba citata de operibus Patrum Cappadociae adhibita ab Ioanne Paulo II in „Angelus Domini”, in institutionibus inter audientias generales dictis, in homiliis in Basilica S. Petri seu Romae habitis et in orationibus ad tempus locutis. Horum Papa pleraque verba inter audientias generales protulit ea ratione, quoniam natura institutionis apud Papam prope actioni pastorali Patrum Ecclesiae est. Nam ut pastores in primis religionis Christianae saeculis, ita Summus Pontifex nostris temporibus, Ioannes Paulus II, eandem doctrinam ad fidem et mores pertinentiam susceperunt. 